\title{
Reinforcement-Related Regulation of AMPA Glutamate Receptor Subunits in the Ventral Tegmental Area Enhances Motivation for Cocaine
}

\author{
Kwang Ho Choi, ${ }^{1}$ Scott Edwards, ${ }^{1}$ Danielle L. Graham, ${ }^{1}$ Erin B. Larson, ${ }^{1}$ Kimberly N. Whisler, ${ }^{1}$ Diana Simmons, ${ }^{1}$ \\ Allyson K. Friedman, ${ }^{2}$ Jessica J. Walsh, ${ }^{2}$ Zia Rahman, ${ }^{1}$ Lisa M. Monteggia, ${ }^{1}$ Amelia J. Eisch, ${ }^{1}$ Rachael L. Neve, ${ }^{3}$ \\ Eric J. Nestler, ${ }^{1}$ Ming-Hu Han, ${ }^{1,2}$ and David W. Self ${ }^{1}$ \\ ${ }^{1}$ Department of Psychiatry, The Seay Center for Basic and Applied Research in Psychiatric Illness, University of Texas Southwestern Medical Center, Dallas, \\ Texas 75390-9070, 2Department of Pharmacology and Systems Therapeutics, Mount Sinai School of Medicine, New York, New York 10029, and \\ ${ }^{3}$ Department of Brain and Cognitive Sciences, Massachusetts Institute of Technology, Cambridge, Massachusetts 02139
}

Chronic cocaine use produces numerous biological changes in brain, but relatively few are functionally associated with cocaine reinforcement. Here we show that daily intravenous cocaine self-administration, but not passive cocaine administration, induces dynamic upregulation of the AMPA glutamate receptor subunits GluR1 and GluR2 in the ventral tegmental area (VTA) of rats. Increases in GluR1 protein and GluR $1{ }^{\mathrm{S} 845}$ phosphorylation are associated with increased GluR1 mRNA in self-administering animals, whereas increased GluR2 protein levels occurred despite substantial decreases in GluR2 mRNA. We investigated the functional significance of GluR1 upregulation in the VTA on cocaine self-administration using localized viral-mediated gene transfer. Overexpression of GluR1 ${ }^{\mathrm{WT}}$ in rat VTA primarily infected dopamine neurons (75\%) and increased AMPA receptor-mediated membrane rectification in these neurons with AMPA application. Similar GluR1 ${ }^{\text {WT }}$ overexpression potentiated locomotor responses to intra-VTA AMPA, but not NMDA, infusions. In cocaine self-administering animals, overexpression of GluR1 ${ }^{\mathrm{WT}}$ in the VTA markedly increased the motivation for cocaine injections on a progressive ratio schedule of cocaine reinforcement. In contrast, overexpression of protein kinase A-resistant GluR $1^{\mathrm{S} 85 \mathrm{~A}}$ in the VTA reduced peak rates of cocaine self-administration on a fixed ratio reinforcement schedule. Neither viral vector altered sucrose self-administration, and overexpression of GluR ${ }^{\mathrm{WT}}$ or GluR ${ }^{\mathrm{S} 845 \mathrm{~A}}$ in the adjacent substantia nigra had no effect on cocaine self-administration. Together, these results suggest that dynamic regulation of AMPA receptors in the VTA during cocaine self-administration contributes to cocaine addiction by acting to facilitate subsequent cocaine use.

\section{Introduction}

Cocaine self-administration produces numerous neurobiological changes, but relatively few have been related to the behavioral context of reinforcement, where cocaine is administered contingent on the execution of an instrumental response. For example, the release of dopamine, acetylcholine, glutamate, and other neurotransmitters is enhanced by response-contingent cocaine administration (Wilson et al., 1994; Zhang et al., 1994; Dworkin et al., 1995; Hemby et al., 1997; Mark et al., 1999; You et al., 2007), and self-administered cocaine produces differential effects on gene expression compared to passive administration of cocaine (Freeman et al., 2002; Jacobs et al., 2002; Thomas et al., 2003;

Received Nov. 16, 2010; revised April 15, 2011; accepted April 18, 2011.

Author contributions: K.H.C., D.S., L.M.M., A.J.E., M.-H.H., and D.W.S. designed research; K.H.C., S.E., D.L.G., E.B.L., K.N.W., D.S., A.K.F., J.J.W., Z.R., M.-H.H., and D.W.S. performed research; Z.R., L.M.M., R.L.N., and E.J.N. contributed unpublished reagents/analytic tools; K.H.C., E.B.L., D.S., A.J.E., M.-H.H., and D.W.S analyzed data; K.H.C., M.-H.H., and D.W.S wrote the paper.

This work is supported by United States Public Health Service Grant DA 18743 and the Wesley Gilliland Professorship in Biomedical Research (University of Texas Southwestern Medical Center).

Correspondence should be addressed to David W. Self, Department of Psychiatry, University of Texas Southwestern Medical Center, Dallas, TX75390-9070. E-mail: david.self@utsouthwestern.edu.

DOI:10.1523/JNEUROSCI.6014-10.2011

Copyright $\odot 2011$ the authors $\quad 0270-6474 / 11 / 317927-11 \$ 15.00 / 0$
Stefanski et al., 2007; Miguens et al., 2008). There are even fewer instances where such response-contingent regulation has been shown to act reciprocally to directly influence cocaine reinforcement itself. Such reciprocal interaction between reinforcementrelated neurobiological change and subsequent cocaine-seeking behavior is critical to understanding the pathological process of cocaine addiction.

Dopamine neurons in the ventral tegmental area (VTA) play a key role in the reinforcing effects of cocaine. Previous studies found that even a single exposure to cocaine can lead to a transient enhancement in the excitability of dopamine neurons resulting from increased sensitivity to AMPA glutamate receptor stimulation (White et al., 1995; Zhang et al., 1997) and potentiated synaptic responses resembling long-term potentiation (LTP) in the VTA (Ungless et al., 2001; Saal et al., 2003; Borgland et al., 2004). Repeated cocaine exposure also enhances susceptibility to LTP induction (Liu et al., 2005). This transient enhancement in VTA dopamine neuron excitability may persist for up to $5 \mathrm{~d}$ after passive cocaine administration (Zhang et al., 1997; Ungless et al., 2001; Borgland et al., 2004). However, in cocaine self-administering animals, increased AMPA-mediated excitation of VTA dopamine neurons per- 
sists for up to 3 months of withdrawal and does not occur in animals that receive cocaine passively via yoked intravenous injections (Chen et al., 2008). Thus, this long-lasting neuroplasticity is related specifically to the reinforcing context of cocaine self-administration.

Neuroplasticity in VTA dopamine neurons could be driven by changes in the amount of AMPA receptor subunits or phosphorylation of the GluR1 subunit at serine residues 831 and 845, which are both necessary and sufficient for AMPA receptor trafficking in synaptic membranes (Malinow and Malenka, 2002; Song and Huganir, 2002; Esteban et al., 2003; Derkach et al., 2007). Neurobiological changes that alter the excitability of dopamine neurons could profoundly affect motivational responses to drugs of abuse and promote cocaine-seeking behavior during abstinence when exposed to drug-associated environmental cues and stress that activate this system (Stewart, 1983; Berridge and Robinson, 1998; Self and Nestler, 1998; Stewart, 2000; Shalev et al., 2002; Phillips et al., 2003; Self and Choi, 2004). Here, we found that cocaine self-administration dynamically regulates AMPA receptor subunits in the VTA in a manner specific to cocaine reinforcement. We then investigated the functional significance of GluR1 upregulation in the VTA on cocaine selfadministration behavior using viral-mediated gene transfer to overexpress GluR1 in VTA neurons.

Preliminary behavioral data were previously reported (Choi et al., 2003).

\section{Materials and Methods}

Experimental animals and surgery. Male Sprague Dawley rats, weighing 275-300 g on arrival (Charles River), were housed individually in a climate-controlled environment $\left(21^{\circ} \mathrm{C}\right)$ on a $12 \mathrm{~h}$ light/dark cycle. All animals were maintained according to the guidelines of the National Institutes of Health and approved by the Institutional Animal Care and Use Committee of the University of Texas Southwestern Medical Center. To facilitate acquisition of cocaine self-administration, animals were temporarily maintained on a restricted diet of lab chow at $85 \%$ of their original body weight and trained to lever press for $45 \mathrm{mg}$ sucrose pellets on a fixed ratio 1 (FR1) reinforcement schedule until acquisition criteria were achieved ( 100 pellets self-administered for 3 consecutive days). Animals were then fed ad libitum for at least $1 \mathrm{~d}$ before surgery.

Under sodium pentobarbital anesthesia (60 mg/kg, i.p.), a catheter composed of SILASTIC tubing (Green Rubber) and treated with tridodecylmethyl ammonium chloride heparin (Polysciences) was surgically placed in the animal's jugular vein. The catheter was secured with Mersilene surgical mesh (General Medical) at the jugular vein and passed subcutaneously to exit the animal's back through a 22 gauge cannula (Plastics One) imbedded in dental cement on a Marlex surgical mesh (Bard). For experiments with brain infusions, animals also underwent stereotaxic surgery to implant 26 gauge bilateral guide cannulae (Plastics One) in the VTA or the substantia nigra (SN). Stereotaxic coordinates for the VTA and the SN were $-5.6 \mathrm{~mm}$ posterior to bregma, $\pm 0.8 \mathrm{~mm}$ (VTA) or $\pm 1.5 \mathrm{~mm}(\mathrm{SN})$ lateral, and $-7.0 \mathrm{~mm}$ ventral to dura (Paxinos and Watson, 1998). Dummy cannulae (33 gauge) were left in place throughout the experiment. Animals received a prophylactic injection of penicillin $(60,000 \mathrm{IU} / 0.2 \mathrm{ml}$, i.m.) and antibiotic ointment to the catheter exit wound daily. Catheters were flushed daily with $0.2 \mathrm{ml}$ of heparinized $(20 \mathrm{U} / \mathrm{ml})$, bacteriostatic saline containing gentamycin sulfate $(0.33 \mathrm{mg} / \mathrm{ml})$.

Cocaine self-administration. Operant chambers (Med Associates) for cocaine and sucrose self-administration were contextually different from the animals' home cage and located in different rooms. Each chamber was equipped with an infusion pump (Razel Model A pump) and $10 \mathrm{ml}$ glass syringe connected to a fluid swivel (Instech) by Teflon tubing. Tygon tubing enclosed by a metal spring connected the swivel to the animal's catheter exit port and was secured to Teflon threads on the catheter assembly. After 1 week of recovery from surgery, animals were trained to self-administer cocaine in $4 \mathrm{~h}$ sessions for $5-6 \mathrm{~d}$ /week. A single leverpress response at the active lever produced a $0.5 \mathrm{mg} / \mathrm{kg}$ intravenous injection of cocaine (National Institute on Drug Abuse) delivered in 0.05 $\mathrm{ml}$ saline over $2.5 \mathrm{~s}$, concurrent with illumination of a cue light located above the active lever while the house light was extinguished. Each injection was followed by an additional $12.5 \mathrm{~s}$ time-out (TO) period when the house light remained off, and active lever-press responses had no scheduled consequence during this period. Responses on the inactive lever were recorded but had no consequences.

Western blot and quantitative PCR. Animals were trained to selfadminister cocaine for 3 weeks as described above, and brain tissue was collected at different time points (immediately after the final session, and after $1 \mathrm{~d}$ and 3 weeks of withdrawal). Self-administering rats were paired with yoked partners that received an identical amount and temporal pattern of cocaine injections but not contingent on lever-press behavior. An additional group of animals received yoked cocaine injections for the first time during the final session after receiving yoked saline injections in previous sessions to compare with the chronic cocaine groups with no withdrawal. Another group of animals self-administered saline throughout all sessions to control for potential surgical or other influences relating to the testing procedures.

For determination of AMPA and NMDA receptor subunit levels and their phosphorylation status, brain tissue from the VTA and the SN was dissected after brief (1.6 s) microwave irradiation $(5 \mathrm{~kW})$ aimed at the head (Muromachi Kikai) as described previously (Edwards et al., 2007). After microwave fixation, VTA and SN tissue was obtained from chilled coronal brain slices (approximately -4.8 to $-6.3 \mathrm{~mm}$ posterior to bregma) using a 16 gauge punch. Immediately after brain dissection, tissue was homogenized by sonication and boiled for $5 \mathrm{~min}$ in lysis buffer (320 nм sucrose, 5 nм HEPES, 50 nм NaF, 1 mм EGTA, 1 mм EGTA, 1\% SDS containing Protease Inhibitor Cocktail and Phosphatase Inhibitor Cocktails I and II; Sigma) and stored at $-80^{\circ} \mathrm{C}$ until further analysis.

After protein determination by the Lowry method, $20-40 \mu \mathrm{g}$ protein aliquots were separated by SDS-PAGE on $7.5-10 \%$ acrylamide using Tris/glycine/SDS buffer (Bio-Rad) and electrophoretically transferred to PVDF membranes. Membranes were blocked with $5 \%$ nonfat dry milk in PBS containing $0.1 \%$ Tween 20 overnight at $4^{\circ} \mathrm{C}$, washed and incubated in affinity-purified rabbit polyclonal anti-pGluR1 ${ }^{\mathrm{S} 831}$ or anti-pGluR1 $1^{\mathrm{S} 845}$ (1:2500; Millipore), and stripped and reprobed with antibodies for total GluR1 protein (1:5000; Millipore). Other blots were probed with antibodies for GluR2, NR2A, NR2B, or mouse monoclonal anti-glutamic acid decarboxylase (GAD; 1:5000; Millipore), or anti-pTH ${ }^{\mathrm{S} 40}$ (1:1500; Cell Signaling Technology) followed by mouse monoclonal anti-tyrosine hydroxylase (TH; 1:200,000; Millipore). All blots were stripped and reprobed for $\beta$-tubulin as a protein loading control. After labeling with primary antibodies, blots were washed and labeled with the appropriate species-specific peroxidase-conjugated secondary antibodies $(1: 25,000$; Vector Laboratories). Labeled proteins were detected by enhanced chemiluminescence, and densitized using the NIH image 1.57 as described previously (Edwards et al., 2007). Under these conditions, target protein amounts were linear over a threefold to fourfold range. Each blot contained tissue from five or six age- and group-matched untreated controls that remained in their home cages but were handled daily to allow normalization of data between blots.

In separate study groups, tissue was dissected without microwave fixation in animals killed immediately or $1 \mathrm{~d}$ after withdrawal from chronic yoked or self-administered cocaine. Total RNA was extracted from the VTA tissue using Trizol reagent (Invitrogen), precipitated with isopropanol, and treated with DNase to remove genomic DNA (Ambion). RNA was reverse transcribed to cDNA using a first-strand synthesis kit (Invitrogen). Cycle thresholds (Cts) were determined in triplicates of each sample by the $\Delta \Delta \mathrm{Ct}$ method using the following primer sequences: GluR1, 5'GTCCGCCCTGAGAAATCCAG-3', 5'-CTCGCCCTTGTCGTACCAC-3'; GluR2， 5'-GCCGAGGCGAAACGAATGA-3'， 5'-CACTCTCGATGCCATATACGTTG-3'; glyceraldehyde-3-phosphate dehydrogenase (GAPDH): 5'-AACGACCCCTTCATTGAC-3', 5' -TCCACGACATACTCAGCAC-3'.

Characterization of HSV-GluR1 vectors in vitro and in vivo. PC12 cells (Clontech) were plated at a density of $10^{6}$ cells per well on $35 \mathrm{~mm}$ culture plates maintained at $37^{\circ} \mathrm{C}, 5 \% \mathrm{CO}_{2}$ in DMEM supplemented with $10 \%$ 
fetal calf serum and a $1 \%$ solution of $5000 \mathrm{U} / \mathrm{ml}$ penicillin and 5000 $\mu \mathrm{g} / \mathrm{ml}$ streptomycin (Invitrogen) as described previously (Kumar et al., 2005). Cells were infected with $1 \mu \mathrm{l} \mathrm{HSV}$ vectors per well $\left(4.0 \times 10^{7}\right.$ infectious units $/ \mathrm{ml}$ ) after $70-80 \%$ confluence in $35 \mathrm{~mm}$ wells as described previously (Bachtell et al., 2008). After $24 \mathrm{~h}$, cells were incubated for $30 \mathrm{~min}$ with either $5 \mu \mathrm{M}$ forskolin, phorbol-12-myristate-13-acetate (PMA), or fresh medium. Cells were harvested using a lysis buffer $(1 \%$ SDS, 20 mм HEPES, pH 7.4, $100 \mathrm{~mm} \mathrm{NaCl}, 20 \%$ glycerol, 1 mм EDTA, 1 mM EGTA, $10 \mu \mathrm{g} / \mathrm{ml}$ leupeptin, $10 \mu \mathrm{g} / \mathrm{ml}$ aprotinin, $10 \mu \mathrm{g} / \mathrm{ml}$ pepstatin, $1 \mathrm{~mm}$ phenylmethylsulphonyl fluoride, $50 \mathrm{~mm} \mathrm{NaF}, 0.1 \mathrm{~mm}$ sodium orthovanadate, and $10 \mathrm{~mm}$ sodium pyrophosphate) and briefly sonicated and centrifuged, and levels of GluR1, pGluR $1{ }^{\mathrm{S} 845}$, and pGluR1 ${ }^{\mathrm{S} 831}$ were determined in $20 \mu$ g protein aliquots by Western blot as described above. Uniformity of protein loading concentration was confirmed with Ponceau S solution staining (Sigma).

For immunocytochemistry and confocal microscopy of HSV-GluR1 overexpression, naive rats received unilateral stereotaxic infusions of HSV-GluR1 ${ }^{\text {WT }}$ or HSV-GluR1 ${ }^{\text {S845A }}(1.0 \mu \mathrm{l} /$ side) in the VTA, whereas the contralateral side (balanced left and right) received infusions of the PBS solution delivered through 26 gauge Hamilton microsyringes at 5.6 $\mathrm{mm}$ posterior to bregma and $\pm 0.8 \mathrm{~mm}$ lateral and $-8.0 \mathrm{~mm}$ ventral to dura. After $2 \mathrm{~d}$, rats were anesthetized with chloral hydrate and killed via intracardiac perfusion of PBS followed by $4 \%$ paraformaldehyde ( 20 $\min , 12 \mathrm{ml} / \mathrm{min}$ ). The brains were postfixed in $4 \%$ paraformaldehyde overnight and cryoprotected in $20 \%$ glycerol/PBS at $4^{\circ} \mathrm{C}$ for $3 \mathrm{~d}$. Coronal brain sections $(30 \mu \mathrm{m})$ were blocked with $3 \%$ normal donkey serum and $0.3 \%$ Triton X-100 in PBS for 60 min before incubation with rabbit polyclonal anti-GluR1 (1:1000; Millipore) and mouse monoclonal anti-TH (1:5000; Millipore) in 3\% normal donkey serum and $0.3 \%$ Tween 20 for $18-20 \mathrm{~h}$. After washing with PBS, sections were incubated with fluorescent-tagged secondary antibodies for $60 \mathrm{~min}$ (Cy2-conjugated donkey anti-mouse for TH; Cy3-conjugated donkey anti-rabbit for GluR1; Jackson ImmunoResearch). After incubation with secondary antibodies, VTA sections were counterstained with DAPI (1:5000; Roche Applied Science) for $20 \mathrm{~min}$ at room temperature. VTA sections were sequentially dehydrated in 70, 95, and 100\% of ethanol and Citrosolv, and coverslipped with DPX (Sigma-Aldrich). Negative controls for antibody labeling indicated a lack of specific staining when the primary antibody was omitted or diluted.

Confocal microscopy was performed to quantify the relative percentage of ectopic HSV-GluR1 expression in TH-positive neurons and to determine the percentage of infected $\mathrm{TH}$-positive neurons within a 0.5 mm diameter zone of highest HSV-mediated GluR1 expression in the VTA. Simultaneous epifluorescence (Cy2 and $\mathrm{Cy} 3$ ) images were obtained at $20 \times$ and $63 \times$ magnification with a laser-scanning confocal microscope (Zeiss Axiovert 200 and LSM510-META) using three lasers comprised of argon $(458,477,488$, and $514 \mathrm{~nm}), \mathrm{HeNe} 1(543 \mathrm{~nm})$, and $\mathrm{HeNe} 2(633 \mathrm{~nm})$. Laser-scanning and optical sectioning in the $Z$ plane were performed using multitrack scanning with a section thickness of $1.45 \mu \mathrm{m}$ for $20 \times$ or $0.45 \mu \mathrm{m}$ for $63 \times$ magnification (Donovan et al., 2008). Colocalization was assessed by analysis of adjacent $Z$ sections, orthogonal sectioning through $Z$ sections, and three-dimensional reconstruction with rotation. Confocal images were imported into Adobe Photoshop (Adobe Systems) for composition of merged images. Single- and double-labeled GluR1 ${ }^{\text {WT }}$ and TH-positive cells were counted within the infected region across three slices per animal and averaged to obtain an individual percent colocalization for each of six animals. The mean percentage of colocalization across animals was determined and expressed as both a percentage of $\mathrm{TH}$-positive expression in ectopic GluR1 ${ }^{\mathrm{WT}}$ expressing cells and the percentage of total TH-positive cells within the infected region that express GluR1 ${ }^{\text {WT }}$. Dendritic labeling of GluR1 in

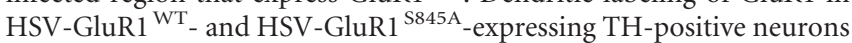
was quantified by measuring the length of GluR1-labeled processes from the soma in three to five cells per animal under blinded conditions and expressed as the mean process length (micrometers per animal; three or four animals per group).

Electrophysiology. VTA slice cultures were prepared from postnatal day 25-35 rats anesthetized with isoflurane as described previously (Han et al., 2006; Krishnan et al., 2007; Cao et al., 2010b). A tissue block contain- ing midbrain was taken and sliced in ice-cold solution containing the following (in mM): 254 sucrose, $3 \mathrm{KCl}, 1.25 \mathrm{NaH}_{2} \mathrm{PO}_{4}, 10$ D-glucose, 24 $\mathrm{NaHCO}_{3}, 2 \mathrm{CaCl}_{2}$, and $2 \mathrm{MgSO}_{4}$. Slices ( $300 \mu \mathrm{m}$ thick) were transferred to a holding chamber in $34^{\circ} \mathrm{C}$ containing artificial CSF (aCSF) containing the following (in $\mathrm{mm}[\mathrm{sCAP}]$ ): $128 \mathrm{NaCl}, 3 \mathrm{KCl}, 1.25 \mathrm{NaH}_{2} \mathrm{PO}_{4}, 10$ D-glucose, $24 \mathrm{NaHCO}_{3}, 2 \mathrm{CaCl}_{2}$, and $2 \mathrm{MgSO}_{4}, \mathrm{pH} 7.35,295-305$ mOsm. After 45-60 min recovery, slices were transferred onto the membrane of Millicell (Millipore) containing culture medium: MEM with $30 \mathrm{~mm}$ HEPES, $20 \mathrm{~mm}$ D-glucose, 5\% B27, $5.0 \mathrm{~mm}$ L-glutamine, and $25 \mathrm{U} / \mathrm{ml}$ streptomycin/penicillin. After $60 \mathrm{~min}$ incubation, GFP-tagged HSVGluR $1{ }^{\text {WT }}$ and HSV-GluR $1^{\text {S845A }}$ vectors were pipetted onto the VTA area of the slice surface. Slices were maintained overnight at $34^{\circ} \mathrm{C}$ and then put into a recording chamber perfused with standard aCSF at a rate of 2.5 $\mathrm{ml} / \mathrm{min}$. All solutions except for culture medium were saturated with $95 \% \mathrm{O}_{2}$ and $5 \% \mathrm{CO}_{2}$. GFP-positive cells were visualized with an upright fluorescence microscope using infrared differential interference contrast illumination. Whole-cell voltage-clamp recordings were performed under continuous single-electrode voltage-clamp mode (AxoClamp 2B; Molecular Devices). Electrodes (2-4 M $\Omega$ ) were filled with pipette solution containing the following (in $\mathrm{mm}$ ): 115 potassium gluconate, $20 \mathrm{KCl}$, $1.5 \mathrm{MgCl}_{2}, 10$ phosphocreatine, 10 HEPES, 2 ATP-Mg, and $0.5 \mathrm{GTP}, \mathrm{pH}$ 7.2, 285 mOsm. Data were acquired using DigiData 1322A and pClamp 8 (Molecular Devices).

In these experiments, putative dopamine neurons in the VTA were identified by large hyperpolarization-activated currents $\left(I_{\mathrm{h}}\right)$ as described previously (Ungless et al., 2003; Cao et al., 2010a). $I_{\mathrm{h}}$ current was evoked by a family of $10 \mathrm{mV}$ voltage steps (duration $600 \mathrm{~ms}$ ) from -60 to -140 $\mathrm{mV}$ holding potentials. In separate experiments, $I_{\mathrm{h}}$-positive neurons were recorded in 150- $\mu \mathrm{m}$-thick slices, and cells were filled with biocytin ( $1 \%$ internal recording solution) using $20 \mathrm{pA}$ depolarized current injections. Slices were fixed immediately after recording in $4 \%$ formaldehyde for $2 \mathrm{~h}$ and then stored at $4^{\circ} \mathrm{C}$ in PBS. Slices were processed for $\mathrm{TH}$ immunoreactivity as discussed above.

AMPA- and NMDA-mediated locomotion. Locomotor activity was recorded in the dark using $1.95 \mathrm{~m}$ circular test chambers with a $12-\mathrm{cm}$-wide runway and equipped with four pairs of photocells located at $90^{\circ}$ intervals. Drug-naive animals with bilateral guide cannulae in the VTA were habituated to the locomotor apparatus for $2 \mathrm{~h}$ before testing and given $1.0 \mu$ lintra-VTA infusions of the HSV vectors through bilateral 33-gauge infusion cannulae extending $1 \mathrm{~mm}$ beyond the guide cannulae tip over a $5 \mathrm{~min}$ period. Infusion cannulae were left in place for an additional $2 \mathrm{~min}$ to allow for diffusion. Each subsequent test session incorporated a $2 \mathrm{~h}$ habituation phase followed by an intra-VTA infusion of either a PBS vehicle, AMPA (10 ng per side, bilateral), or NMDA (500 ng/side, bilateral) in a volume of $0.5 \mu \mathrm{l}$ per side over $100 \mathrm{~s}$ through bilateral 33-gauge infusion cannulae in counterbalanced order over 3 consecutive test days. The injectors were left in place for $30 \mathrm{~s}$ and then gently removed, and the animals were placed back into the locomotor apparatus, where locomotor activity was recorded for $1 \mathrm{~h}$.

HSV-GluR1 overexpression in the VTA and cocaine self-administration. Animals were trained to self-administer cocaine $(0.5 \mathrm{mg} / \mathrm{kg}$ per injection) for 3 weeks as described above, and then the response requirement was raised over subsequent sessions from an FR1 to an FR5 schedule and continued until cocaine intake stabilized to within $10 \%$ of the mean of three consecutive sessions. After stabilization, animals were trained in a within-session FR5 dose-response procedure with each injection dose $(1.0,0.3,0.1,0.03$, and $0 \mathrm{mg} / \mathrm{kg})$ available in descending order in sequential $60 \mathrm{~min}$ components after an initial $30 \mathrm{~min}$ loading phase $(0.5 \mathrm{mg} / \mathrm{kg}$ per injection). The unit dose per injection was adjusted by reducing the injection volume $(0.2,0.06,0.02,0.006$, and $0 \mathrm{ml})$ to produce unit injection doses of $1,0.3,0.1,0.03$, and $0 \mathrm{mg} / \mathrm{kg}$ cocaine, respectively. Animals were trained until the injection dose producing peak self-administration rates remained constant for three consecutive sessions. After stabilization of peak-rate cocaine doses, animals received intra-VTA or intra-SN infusions of the HSV vectors ( $1 \mu$ l per side) through bilateral guide cannulae as described above. Animals were then tested in within-session dose-response tests during HSV-GluR1 overexpression (postinfusion days 2-5) and 7-10 d after HSV infusions, when HSV-mediated overex- 
a

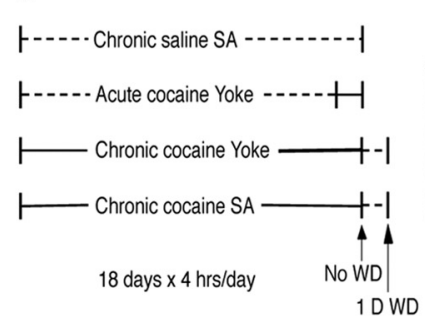

C

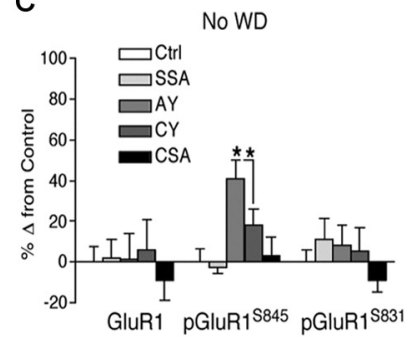

e

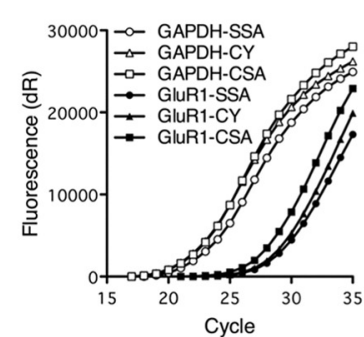

b

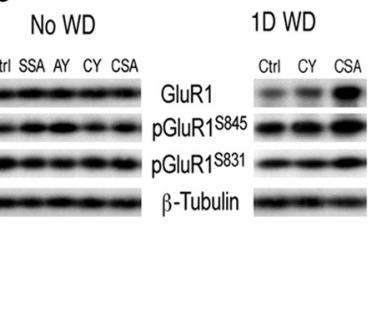

d

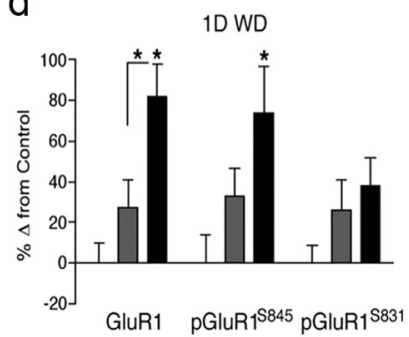

f

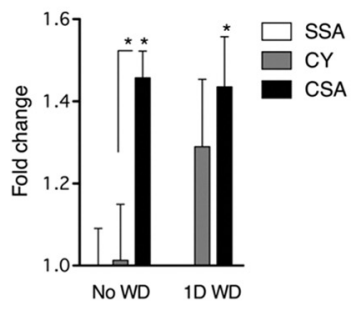

Figure 1. Dynamic regulation of GluR1 levels in the VTA with daily cocaine selfadministration. $\boldsymbol{a}$, Depiction of treatment regimens for self-administering $(S A)$ and yoked animals. $\boldsymbol{b}$, Example immunoblots of total GluR1, pGluR1 ${ }^{5845}$, and pGluR1 ${ }^{\text {S831 }}$ in no withdrawal (NO WD) and $1 \mathrm{~d}$ withdrawal (1D WD) groups. Ctrl, Untreated controls; SSA, saline self-administration; AY, acute yoke; $C Y$, chronic yoke; CSA, cocaine self-administration. C, Total GluR1, pGluR1 ${ }^{5845}$, and pGluR1 ${ }^{5831}$ levels in the VTA in no withdrawal group $(N=$ $8-28$ /group). $\boldsymbol{d}$, Total GluR1, pGluR1 ${ }^{5845}$, and pGluR1 ${ }^{5831}$ levels in the VTA in $1 \mathrm{~d}$ withdrawal group ( $N=13-18 /$ group). e, Quantitative PCR amplification curves of GAPDH and GluR1 mRNA in the VTA. $\boldsymbol{f}$, GluR1 mRNA levels in the VTA in no withdrawal and $1 \mathrm{~d}$ withdrawal groups ( $N=4-6 /$ group). Data are expressed as mean \pm SEM. ${ }^{*} p<0.05$ (significant from control or designated group).

pression is diminished to undetectable levels in the brain (Carlezon et al., 1997; Sutton et al., 2003; Bachtell et al., 2008).

After FR5 dose-response testing, rats were restabilized on the FR5 schedule $(0.5 \mathrm{mg} / \mathrm{kg}$ per injection) in daily $4 \mathrm{~h}$ sessions and then trained on a progressive ratio (PR) schedule at either 0.5 or $1.0 \mathrm{mg} / \mathrm{kg}$ per injection for 2 weeks. The number of active lever presses for each successive cocaine injection increased according to the calculation $\left[5 \mathrm{e}^{\text {(injection number } \times 0.2)}\right]-5$ (i.e., responses per injection increased as 1, 2, 4, 6, 9, 12, 15, 20, 25, 32, 40, 50, etc.). The highest ratio of responses per injection achieved before a $1 \mathrm{~h}$ period when no further injections were earned (break point) was determined in daily tests until they varied $<10 \%$ for 3 consecutive days. Animals then received the same HSV infusions as in FR5 testing, and break points were determined for postinjection days $2-5$ (overexpression) and again on days 7-10 (after expression).

HSV-GluR1 overexpression in the VTA and sucrose pellet selfadministration. Bilateral guide cannulae were implanted in the VTA of drug-naive rats as described above. After a week of recovery, rats were food restricted to $85 \%$ body weight and trained to self-administer sucrose pellets on an FR1:TO $15 \mathrm{~s}$ reinforcement schedule for a maximum of 50 available sucrose pellets. After acquisition, the reinforcement schedule was increased to FR5 for at least 3 weeks and until the latency to consume 50 pellets stabilized to $<10 \%$ variance from the mean of three consecutive sessions. Animals showing stable responses on the FR5

a

No WD

1D WD

\section{Ctrl SSA AY CY CSA Ctrl CY CSA

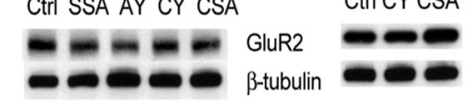

b

No WD

C

1DWD
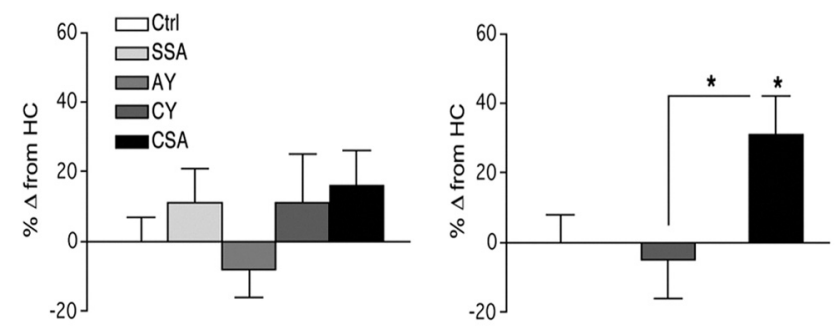

d RT-PCR: 1D WD

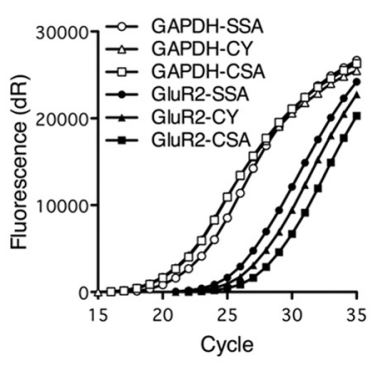

e

GluR2 mRNA

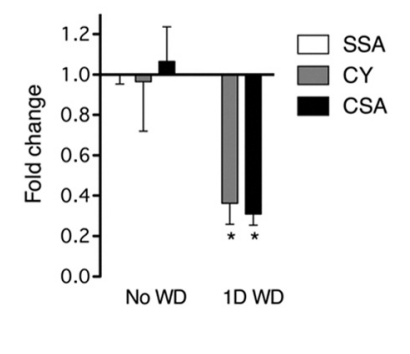

Figure 2. Dynamic regulation of GluR2 levels in the VTA with daily cocaine self-administration. $\boldsymbol{a}$ Example immunoblots of GluR2 in the VTA in no withdrawal (No WD) or $1 \mathrm{~d}$ withdrawal (ID WD) groups. Ctrl, Untreated controls; $S S A$, saline self-administration; $\mathrm{AY}$, acute yoke; $\mathrm{CY}$, chronic yoke; $\mathrm{CSA}$, cocaine self-administration. $\boldsymbol{b}$, GluR2 protein levels in the VTA in no withdrawal group $(N=8-28$ ) group). $\boldsymbol{c}$, GluR2 protein levels in the VTA in $1 \mathrm{~d}$ withdrawal group ( $N=13-18$ /group). $\boldsymbol{d}$, Quantitative PCR amplification curves of GAPDH and GluR2 in the VTA. e, GluR2 mRNA levels in the VTA in no withdrawal and $1 \mathrm{~d}$ withdrawal groups ( $N=4-6 /$ group). Data are expressed as mean \pm SEM. ${ }^{*} p<$ 0.05 (significant from control or designated group).

Table 1. Levels of total GluR1, pGluR1 ${ }^{\mathrm{S845}}$, pGluR1 ${ }^{\mathrm{S831}}$, and GluR2 proteins in the SN ( $N=11-21 /$ group)

\begin{tabular}{llllllll}
\hline No withdrawal & & & & & & & \\
\cline { 2 - 4 } & AY withdrawal & CY & CSA & Crl $\quad$ CY & CSA
\end{tabular}

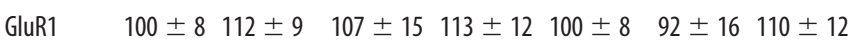

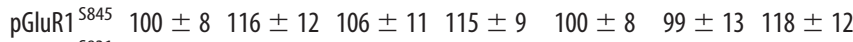
$\begin{array}{llllllll}\text { pGluR1 }^{5831} & 100 \pm 9 & 102 \pm 12 & 110 \pm 11 & 112 \pm 11 & 100 \pm 9 & 104 \pm 17 & 113 \pm 14\end{array}$ GluR2 $\quad 100 \pm 7 \quad 110 \pm 10 \quad 106 \pm 12 \quad 91 \pm 10 \quad 100 \pm 7 \quad 103 \pm 17 \quad 108 \pm 10$

Data are expressed as mean \pm SEM for untreated controls (Ctrl), acute yoke (AY), chronic yoke (CY), and cocaine self-administration (CSA).

Table 2. Levels of TH; pTH ${ }^{540}$; the NMDA receptor subunits NR1, NR2A, and NR2B; and GAD proteins in the VTA ( $N=8-28 /$ group)

\begin{tabular}{|c|c|c|c|c|c|c|c|c|}
\hline & \multicolumn{5}{|c|}{ No withdrawal } & \multicolumn{3}{|c|}{$1 \mathrm{~d}$ withdrawal } \\
\hline & Ctrl & SSA & AY & $C Y$ & CSA & Ctrl & $\mathrm{CY}$ & CSA \\
\hline TH & $100 \pm 4$ & $93 \pm 4$ & $100 \pm 7$ & $95 \pm 6$ & $102 \pm 6$ & $100 \pm 6$ & $107 \pm 8$ & $103 \pm 9$ \\
\hline $\mathrm{pTH}^{\mathrm{S} 40}$ & $100 \pm 9$ & $121 \pm 11$ & $134 \pm 17$ & $89 \pm 12$ & $119 \pm 10$ & $100 \pm 10$ & $111 \pm 16$ & $73 \pm 7$ \\
\hline NR1 & $100 \pm 5$ & $96 \pm 5$ & $113 \pm 9$ & $112 \pm 6$ & $110 \pm 6$ & $100 \pm 15$ & $119 \pm 11$ & $99 \pm 13$ \\
\hline NR2A & $100 \pm 6$ & $102 \pm 9$ & $100 \pm 8$ & $96 \pm 9$ & $101 \pm 10$ & $100 \pm 13$ & $119 \pm 15$ & $119 \pm 11$ \\
\hline NR2B & $100 \pm 7$ & $111 \pm 10$ & $101 \pm 10$ & $104 \pm 11$ & $99 \pm 9$ & $100 \pm 10$ & $103 \pm 16$ & $111 \pm 22$ \\
\hline GAD & $100 \pm 5$ & $107 \pm 5$ & $105 \pm 5$ & $110 \pm 5$ & $115 \pm 7$ & $100 \pm 6$ & $103 \pm 7$ & $110 \pm 4$ \\
\hline
\end{tabular}

Data are expressed as mean \pm SEM for untreated controls (Ctrl), acute yoke (AY), chronic yoke (CY), and cocaine self-administration (CSA).

schedule received intra-VTA infusions of HSV vectors and were tested during HSV-GluR1 overexpression (2-5 d after infusion). Animals were given a 1 week break from food self-administration and then trained on a progressive ratio schedule until break points stabi- 
a

HSV

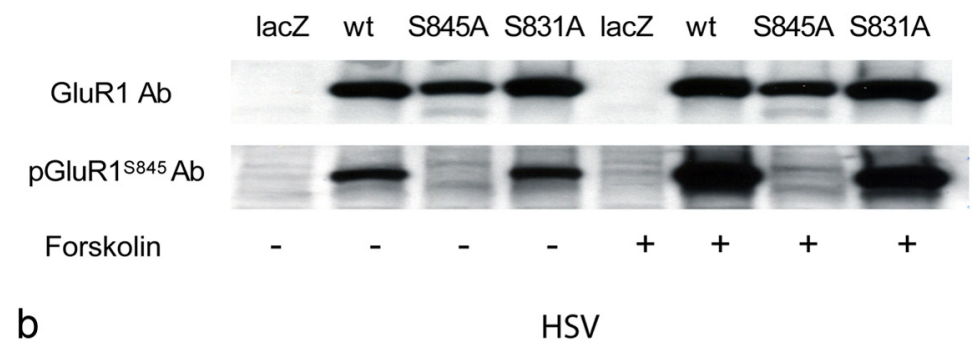

lacZ wt S845A S831A lacZ wt S845A S831A

GluR1 Ab

pGluR1 $1831 \mathrm{Ab}$

PMA

C

HSV GluR 1

overexpression
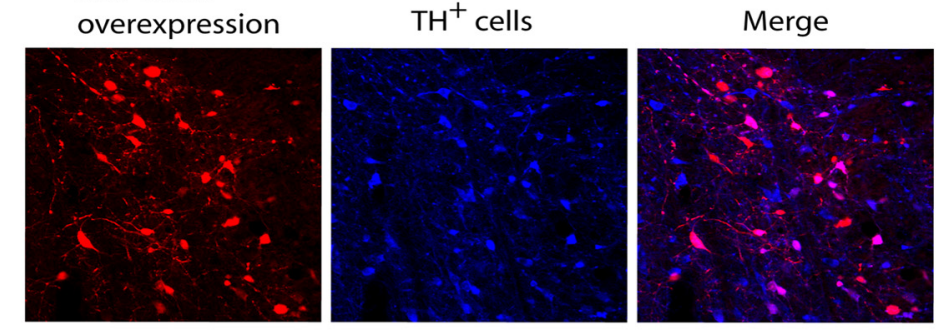

d
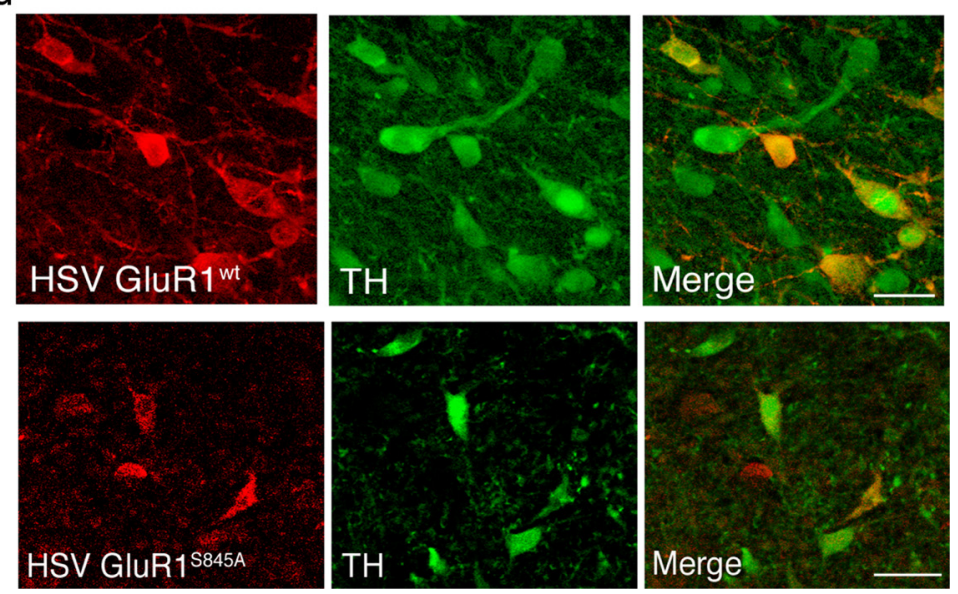

Figure 3. Characterization of HSV-GluR1 vectors in vitro and in vivo. $\boldsymbol{a}, \mathrm{HSV}$-mediated overexpression of GluR1 ${ }^{\mathrm{WT}}$ and phosphorylation-resistant GluR1s in PC12 cells. Forskolin treatment $(5 \mu \mathrm{m})$ increased PKA-mediated phosphorylation of GluR1 ${ }^{5845}$ shown in cells infected with HSV-GluR1 ${ }^{\text {WT }}$ and HSV-GluR1 ${ }^{\text {S831A }}$. b. PMA treatment $(5 \mu \mathrm{M})$ increased PKC-mediated phosphorylation of GluR1 shown in cells infected with HSV-GluR1 ${ }^{\text {WT }}$ and HSV-GluR1 ${ }^{5845 A}$. c, Overexpression of GluR1 (red) in VTA dopamine neurons (blue) after intra-VTA HSV- GluR1 ${ }^{\text {WT }}$ infusions in rats. $\boldsymbol{d}$, Reduced dendritic labeling of GluR1 immunoreactivity in cells infected with PKA-resistant HSV-GluR1 ${ }^{\text {S845A }}$ compared to HSV-GluR1 ${ }^{\text {WT }}$. Scale bars: $20 \mu \mathrm{m}$.

lized on the following schedule progression: $1,2,5,9,13,19,25,33$, $41,51,61,76,91,111$, etc. Animals then received the same HSV vectors in the VTA, and break points were determined during GluR1 overexpression (2-5 d after infusion).

After completion of behavioral testing, animals were anesthetized with chloral hydrate $(300 \mathrm{mg} / \mathrm{kg}$, i.p.), and bilateral infusions of $0.5 \mu \mathrm{l}$ cresyl violet were delivered in the VTA or SN through the guide cannulae. Five minutes after the cresyl violet infusions, animals were decapitated, brains were dissected, and infusion sites were identified in $1 \mathrm{~mm}$ coronal slices.
Only animals with correct bilateral infusion sites in the VTA and the SN were included in the data analysis.

Data analysis. Biological and locomotor data were analyzed by one-factor ANOVA across study groups, or unpaired $t$ tests if only two groups were compared. Self-administration data were analyzed by two-factor ANOVA (dose by HSV treatment) with repeated measures on dose (FR only), and by one-factor ANOVA at each dose followed by post hoc tests with Fisher's least significant difference test. Statistical significance was preset at $p<0.05$.

\section{Results}

Reinforcement-related regulation of GluR1 and GluR2 in the VTA during cocaine self-administration

Animals were allowed to self-administer intravenous cocaine injections for $4 \mathrm{~h}$ per day over $18 \mathrm{~d}$, and brain tissue was collected at different time points after the final self-administration session (no withdrawal, $1 \mathrm{~d}$ withdrawal, or 3 weeks withdrawal). Each self-administering animal was yoked to an animal that received the same number and temporal pattern of cocaine injections passively and independent of lever-press behavior (Fig. 1a). Cocaine self-administration was stable by the third week of training, with average daily intake (days 13-18) ranging from 44.8 to $50.2 \mathrm{mg} / \mathrm{kg}$ in self-administering animals and their chronic yoked partners. After $1 \mathrm{~d}$ withdrawal from cocaine selfadministration, GluR1 protein levels were increased by $82 \%$ in the VTA when compared to untreated controls $\left(F_{(2,44)}=\right.$ 10.020; $p=0.001)$, but GluR1 levels were not altered in animals that received cocaine by passive yoked injection (Fig. $1 b, d)$. These results indicate that GluR 1 regulation was related to cocaine delivery in a response-contingent (reinforcing) manner. Increases in GluR1 protein levels in self-administering animals were paralleled by a $74 \%$ increase in protein kinase $\mathrm{A}$ (PKA)-mediated GluR1 ${ }^{\mathrm{S} 845}$ phosphorylation $\left(F_{(2,44)}=3.887 ; p=0.028\right)$, but not GluR1 ${ }^{\mathrm{s} 831}$ phosphorylation mediated by protein kinase C (PKC) and/or calcium/ calmodulin-dependent kinase II (CaMKII). Concomitant increases in phosphorylated and total GluR1 suggest that GluR1 ${ }^{\text {S845 }}$ phosphorylation is coregulated with the total amount of GluR1 protein in VTA neurons rather than enhanced PKA activity per se. Since GluR1 ${ }^{\mathrm{S} 845}$ phosphorylation is necessary and sufficient for extrasynaptic membrane insertion of newly synthesized AMPA receptors (Song and Huganir, 2002; Esteban et al., 2003; Derkach et al., 2007), these findings suggest an increase in GluR1-containing AMPA receptors in extrasynaptic membranes after $1 \mathrm{~d}$ withdrawal from cocaine self-administration. 
Levels of total GluR1 and GluR1 ${ }^{\mathrm{S} 845}$ phosphorylation were normalized immediately after a return to $4 \mathrm{~h}$ of cocaine selfadministration (Fig. 1c). At the same time, GluR1 mRNA increased by $\sim 1.45$-fold in the VTA in cocaine self-administering but not yoked animals, and this increase persisted after $1 \mathrm{~d}$ cocaine withdrawal (Fig. 1e,f) $\left(F_{(4,20)}=5.212 ; p=0.005\right)$. Together, these findings indicate that increased GluR1 protein after $1 \mathrm{~d}$ cocaine withdrawal likely results from reinforcement-related activation of GluR1 gene expression during and after cocaine self-administration, but GluR1 protein may be degraded during cocaine self-administration, resulting in dynamic daily fluctuations in GluR1 levels during ongoing cocaine use. In contrast to chronic cocaine self-administration, an initial exposure to passive yoked cocaine injections in drug-naive animals increased PKA-mediated GluR1 ${ }^{\mathrm{S} 445}$ phosphorylation by $40 \%\left(F_{(4,77)}=4.495 ; p=0.03\right)$, but tolerance developed to acute cocaine regulation of GluR ${ }^{5845}$ phosphorylation after chronic yoked administration (Fig. 1b,c).

The GluR2 AMPA receptor subunit displayed a similar reinforcement-related $31 \%$ upregulation in the VTA after $1 \mathrm{~d}$ withdrawal from self-administered but not yoked cocaine (Fig. $2 a--c)\left(F_{(2,44)}=3.95 ; p=0.026\right)$. GluR2 levels were normalized along with GluR1 immediately after return to $4 \mathrm{~h}$ of cocaine self-administration. However, in contrast to GluR1 upregulation, increases in GluR2 protein occurred despite a substantial 64-69\% reduction in GluR2 mRNA in both chronic yoked and self-administering animals after $1 \mathrm{~d}$ withdrawal (Fig. 2d,e) $\left(F_{(4,21)}=4.253 ; p=0.011\right)$. Thus, reinforcement-related upregulation of GluR2 protein is uncoupled from downregulation in GluR2 mRNA in the VTA.

There were no changes in the phosphorylation or amount of GluR1 and GluR2 in animals self-administering saline injections throughout the $18 \mathrm{~d}$ of training compared to untreated controls (Figs. 1c, 2b), indicating a lack of surgical or procedural influences unrelated to cocaine self-administration. In addition, regulation of GluR1 and GluR2 in cocaine self-administering animals occurred specifically in the mesolimbic dopamine system, since there was no regulation in adjacent $\mathrm{SN}$ tissue (Table 1), and cocaine administration (self or passive) failed to regulate the NMDA glutamate receptor subunits NR1, NR2A, and NR2B in the VTA (Table 2). Moreover, Table 2 shows there was no regulation of the dopamine- and GABA-synthesizing enzymes TH and $\mathrm{GAD}$, respectively, consistent with our previous TH work in selfadministering animals after $1 \mathrm{~d}$ withdrawal (Schmidt et al., 2001). Finally, reinforcement-related upregulation of GluR1 and GluR2 protein in the VTA failed to endure after 3 weeks withdrawal from chronic cocaine self-administration (data not shown).

\section{Characterization of HSV-GluR1 vectors}

To study the functional role of GluR1 upregulation on cocaine self-administration behavior, we generated HSV vectors expressing wild-type GluR1 or phosphorylation-resistant GluR1 mutants. Figure 3 illustrates HSV-mediated overexpression of GluR1 in vitro (PC12 cells) and in the VTA of rats after in vivo brain infusions. All three viral vectors overexpressed GluR1 in PC12 cells when compared to lacZ-expressing controls (Fig. 3a,b). Treatment with the PKA activator forskolin increased S845 phosphorylation of GluR ${ }^{\text {WT }}$ and the PKC/CaMKII-resistant GluR $1^{\text {S831A }}$, but not the PKA-resistant mutant GluR1 ${ }^{\mathrm{S} 845 \mathrm{~A}}$ as expected. Conversely, treatment with the PKC activator PMA increased S831 phosphorylation of GluR $1^{\mathrm{WT}}$ and the PKAresistant mutant GluR1 ${ }^{8845 \mathrm{~A}}$, but not the PKC/CaMKIIresistant GluR1 ${ }^{\text {S831A }}$. Intra-VTA infusions of HSV-GluR $1^{\text {WT }}$ a
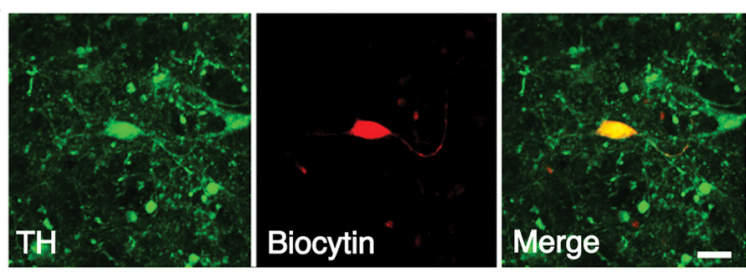

b

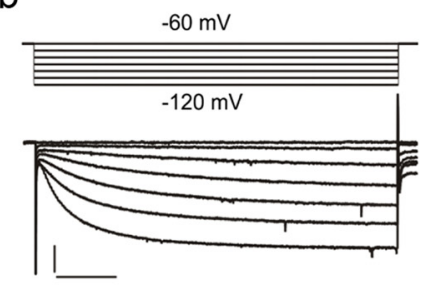

C

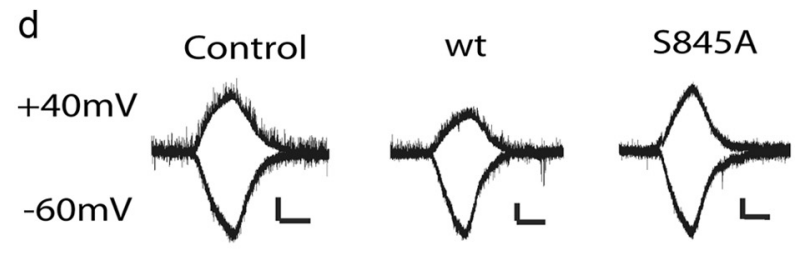

e

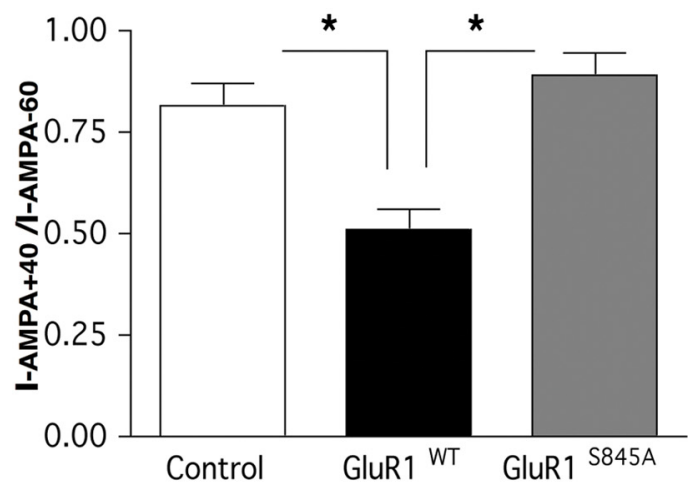

f

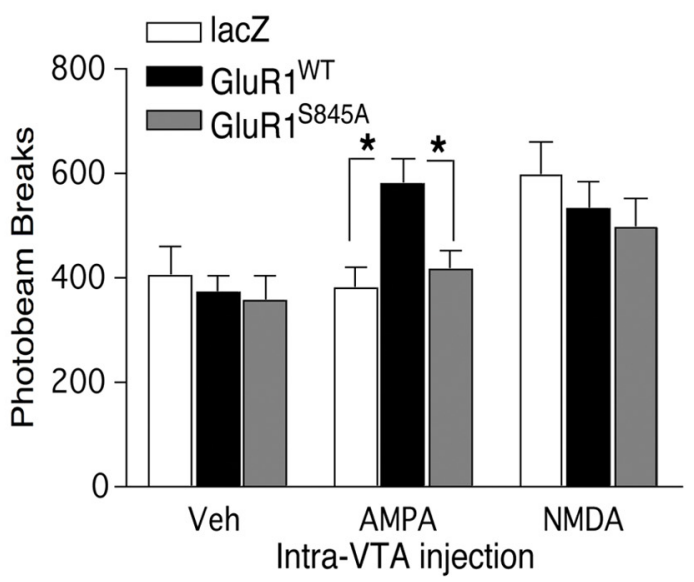

Figure 4. Electrophysiological and behavioral characterization of HSV-GluR1 overexpression in VTA dopamine neurons of rat brain. $\boldsymbol{a}$, Nine of 10 biocytin-labeled neurons (red) with large $I_{h}$ currents stained positive for TH (green) in the VTA. Scale bar, $20 \mu \mathrm{m}$. $\boldsymbol{b}$, Sample traces of $I_{\mathrm{h}}$ currents from TH-positive VTA neurons. Calibration: 100 pA, 30 ms. c, HSV-mediated overexpression of GluR1-GFP protein in a VTA dopamine neuron. $\boldsymbol{d}$, Representative traces of AMPA-mediated (1 $\mu \mathrm{m}$ ) currents in

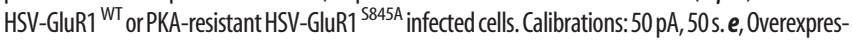
sion of GluR1 ${ }^{\text {WT }}$, but notPKA-resistant GluR1 ${ }^{5845 \mathrm{~A}}$, increases AMPA-mediated rectification currents in VTA dopamine neurons ( $N=5-7$ cells/ group). $f$, Overexpression of GluR1 ${ }^{\text {WT }}$, but not PKA-resistant GluR1 ${ }^{\text {S845A }}$, potentiates locomotor activity induced by intra-VTA AMPA infusions ( $N=7-8 /$ group). Data are expressed as mean \pm SEM. ${ }^{*} p<0.05$ (significant from designated groups). 

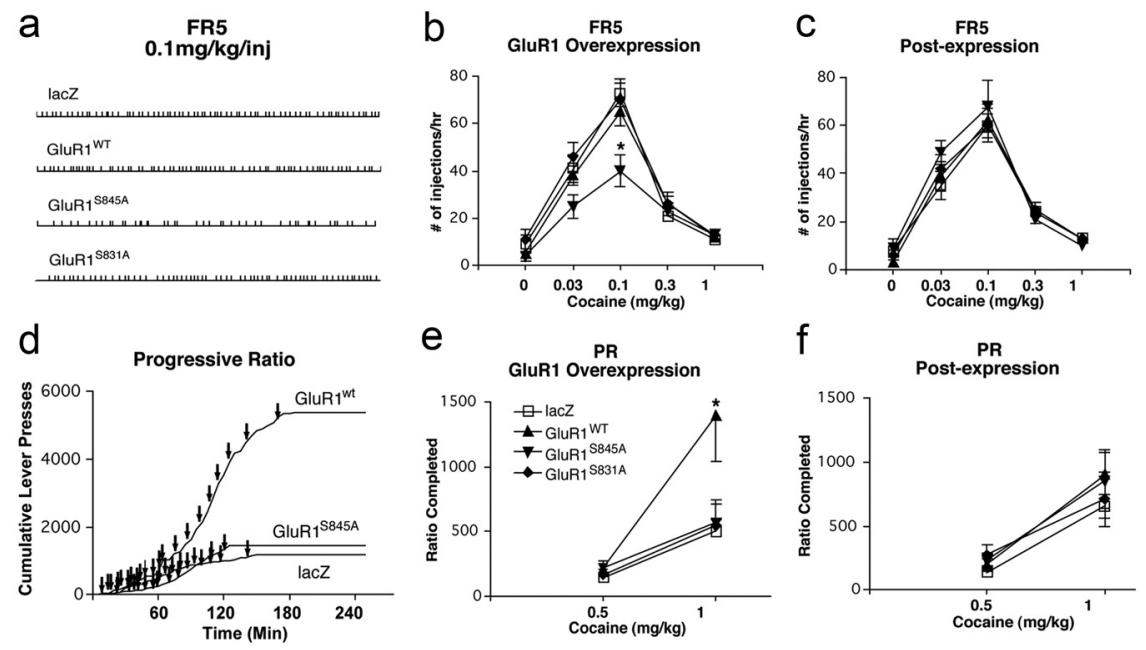

Figure 5. Overexpression of GluR1 ${ }^{\mathrm{WT}}$ in the VTA increases motivation for cocaine. $\boldsymbol{a}$, Representative patterns of cocaine intake (FR5) at $0.1 \mathrm{mg} / \mathrm{kg}$ per injection during overexpression of GluR1 ${ }^{\mathrm{WT}}$ and phosphorylation-resistant GluR1s in the VTA. $\boldsymbol{b}$, PKAresistant GluR1 ${ }^{5845 A}$ overexpression in the VTA reduces peak self-administration rates at a dose of $0.1 \mathrm{mg} / \mathrm{kg}$ cocaine $(N=$ 11-12/group). c, No effect of prior HSV treatment on FR5 cocaine dose-response function was seen after GluR1 overexpression diminished. $\boldsymbol{d}$, Representative cumulative response curves on a progressive ratio schedule of cocaine reinforcement $(1 \mathrm{mg} / \mathrm{kg}$ per injection) during GluR1 ${ }^{\text {WT }}$, PKA-resistant GluR1 ${ }^{\text {S845A }}$, and lacZ overexpression in the VTA (arrows denote times of earned cocaine injections). $\boldsymbol{e}$, GluR $1{ }^{\mathrm{WT}}$ overexpression in the VTA increases the highest response/injection ratio completed (break point) for cocaine at a dose of $1 \mathrm{mg} / \mathrm{kg}$ cocaine ( $N=8-9 /$ group). $f$, No effect of prior HSV treatment on cocaine self-administration break points was seen after GluR1 overexpression diminished. Data are expressed as mean \pm SEM. ${ }^{*} p<0.05$ (significant from lacZexpressing controls).

led to prominent ectopic expression of GluR1 $2 \mathrm{~d}$ later (Fig. $3 c)$. Quantification of the HSV-GluR $1^{\mathrm{WT}}$-infected cells in the VTA revealed that a majority $(75 \%)$ of GluR1 overexpressing cells were TH-positive dopamine neurons ( $N=6$ animals), and that $25 \%$ of all dopamine neurons were infected by HSVGluR $1{ }^{\text {WT }}$ within the infected region.

Higher-magnification microscopy showed that dopamine neurons infected with HSV-GluR $1{ }^{\text {WT }}$ showed prominent GluR1 labeling throughout cell bodies and dendritic processes (Fig. 3d). In contrast, dopamine neurons infected with PKA-resistant HSV-GluR1 ${ }^{\text {S845A }}$ showed GluR1 labeling in cell bodies but with very little dendritic labeling. Quantification of dendritic GluR1 labeling in infected neurons of the VTA found significantly less perisomal labeling with expression of PKA-resistant GluR1 ${ }^{\text {S845A }}$ $\left(27.1 \pm 3.77 \mu \mathrm{m}\right.$ per dendrite) when compared to GluR1 ${ }^{\text {WT }}$ $\left(67.4 \pm 11.9 \mu \mathrm{m}\right.$ per dendrite; $t_{(1,9)}=2.714 ; p=0.024 ; N=3-4$ animals/group), consistent with a recent report showing that GluR1 ${ }^{\mathrm{S} 845}$ phosphorylation facilitates dendritic trafficking of GluR1 in hippocampal neurons (Kessels et al., 2009).

The effect of HSV-GluR1 infection on functional membrane AMPA receptors was examined in VTA slice cultures (Fig. 4a--e). In these slice cultures, $90 \%$ of biocytin-filled VTA neurons that exhibited a large $I_{\mathrm{h}}$ current were TH positive (Fig. $4 a, b$ ). Therefore, putative dopamine neurons in the VTA were identified by the presence of a large $I_{\mathrm{h}}$ current as described previously (Ungless et al., 2003; Cao et al., 2010a). VTA slice cultures were infected with GFP-tagged HSV-GluR1 and GFP-positive neurons exhibiting large $I_{\mathrm{h}}$ currents were recorded by whole-cell voltage clamp (Fig. $4 c--e)$. Current responses to bath-applied AMPA (1 $\mu \mathrm{M})$ were determined at +40 and $-60 \mathrm{mV}$, and the ratio of these currents was used to measure rectification. Figure $4 d$ illustrates that AMPA-induced currents typical in GluR $1{ }^{\text {WT }}$-GFP-expressing VTA neurons show increased rectification at positive potentials compared to noninfected neurons, indicative of an abundance of newly inserted homomeric GluR1-containing AMPA receptors. Overexpression of GluR1 ${ }^{\text {WT }}$-GFP increased rectification by $\sim 40 \%$, whereas overexpression of PKAresistant GluR1 ${ }^{\mathrm{S} 845 \mathrm{~A}}$-GFP had no effect compared to uninfected controls (Fig. 4e). These results indicate that putative dopamine neurons infected by HSV-GluR1 $1^{\text {WT }}$ GFP show physiologically significant membrane incorporation of overexpressed GluR1 ${ }^{\text {WT }}$, but not when infected with the PKA-resistant GluR1 mutant. However, peak currents $(-60 \mathrm{mV})$ elicited by bath application of AMPA failed to differ with overexpression of GluR1 ${ }^{\mathrm{WT}}$-GFP, averaging $128 \pm 23 \mathrm{pA}$ when compared to $136 \pm 25$ $\mathrm{pA}$ (noninfected) and $137 \pm 22 \mathrm{pA}$ (GluR1 $\left.{ }^{\mathrm{S} 845 \mathrm{~A}}-\mathrm{GFP}\right)$, suggesting that homomeric GluR1-containing AMPA receptors may replace existing membrane AMPA receptors.

Overexpression of GluR1 ${ }^{\mathrm{WT}}$ in VTA neurons in vivo also enhanced the locomotor response to intra-VTA infusions of AMPA when compared to LacZ-expressing controls (Fig. $4 f)\left(F_{(3,27)}=20.320 ; p=\right.$ 0.0001 ). In contrast, overexpression of PKA-resistant GluR $1^{\text {S845A }}$ had no effect on AMPA-mediated locomotion, consistent with electrophysiological responses to AMPA described above. In addition, neither GluR $1^{\text {WT }}$ nor GluR $1^{\text {S845A }}$ overexpression in VTA neurons affected the locomotor response to intra-VTA infusions of NMDA, indicating a specific enhancement of AMPA-mediated behavior.

\section{GluR1 overexpression in VTA neurons enhances cocaine reinforcement}

Given that GluR1 in the VTA is dynamically regulated during daily cycles of cocaine self-administration and withdrawal (Fig. 1), we investigated the functional role of GluR1 upregulation in the VTA on cocaine self-administration behavior in rats using fixed and progressive ratio schedules of cocaine reinforcement (Choi et al., 2003). HSV-mediated overexpression of GluR1 ${ }^{\mathrm{WT}}$ had no effect on the rate of cocaine intake with low fixed ratio response demands over a wide dose range (Fig. $5 a, b$ ), but dramatically increased the level of effort exerted by rats to maintain cocaine self-administration on the more demanding progressive ratio schedule of reinforcement (Fig. $5 d, e$ ). This effect is reflected by an almost threefold greater ratio of lever-presses/cocaine injection achieved by rats overexpressing GluR1 $1^{\text {WT }}$ than by lacZexpressing controls when tested at a high cocaine dose $\left(F_{(3,34)}=\right.$ $3.934 ; p=0.0164)$. Conversely, overexpression of the GluR $1^{\mathrm{S} 45 \mathrm{~A}}$ mutant in VTA neurons reduced peak rates of fixed ratio cocaine self-administration at a lower cocaine dose $\left(F_{(3,40)}=4.544 ; p=\right.$ 0.0078 ), but had no effect on the effort exerted for higher-dose cocaine injections on the progressive ratio schedule. These results indicate that VTA expression of GluR1 ${ }^{\text {WT }}$ enhances cocaine reinforcement at higher doses, whereas the PKA-resistant GluR1 ${ }^{\mathrm{S} 845 \mathrm{~A}}$ mutant may have a moderate dominant-negative effect on cocaine reinforcement that is evident at lower threshold doses for maintaining self-administration behavior. The effects of HSVGluR1 ${ }^{\text {WT }}$ and HSV-GluR ${ }^{\text {S845A }}$ on fixed and progressive ratio cocaine self-administration had diminished completely $7-10 \mathrm{~d}$ after 

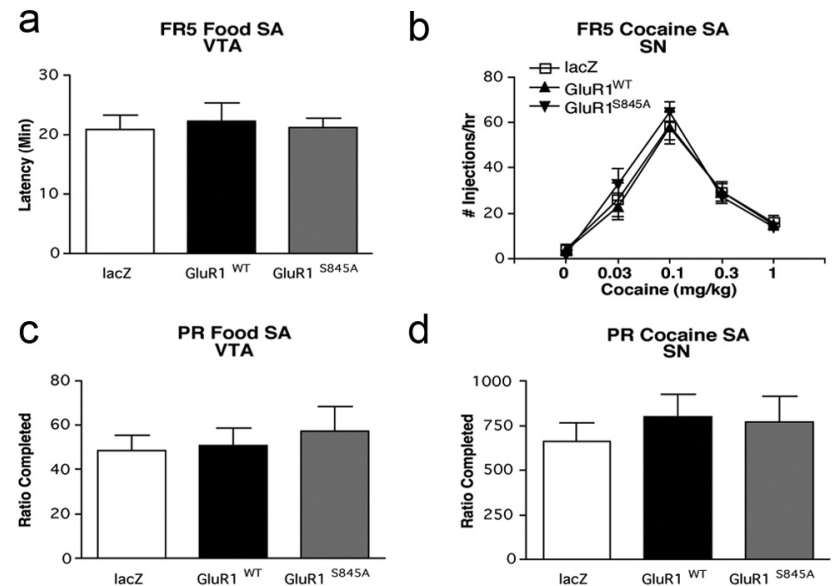

d

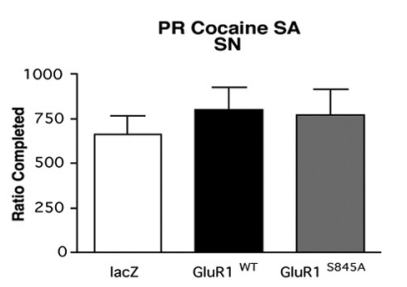

e

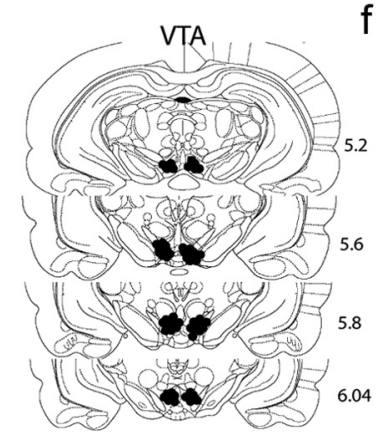

$f$

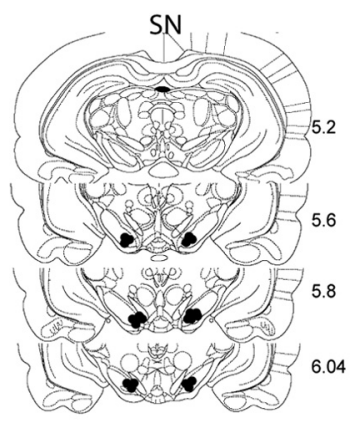

Figure 6. Overexpression of GluR1 in the VTA does not affect sucrose pellet selfadministration, and GluR1 overexpression in the SN does not affect cocaine self-administration behavior. $\boldsymbol{a}$, No effects of GluR1 ${ }^{\mathrm{WT}}$ or GluR1 ${ }^{\mathrm{S} 845 \mathrm{~A}}$ overexpression in the VTA on the latency to self-administer (FR5) 100 sucrose pellets were seen ( $N=6 /$ group). $\boldsymbol{b}$, No effects of GluR1 ${ }^{\text {WT }}$ or GluR1 ${ }^{5845 \mathrm{~A}}$ overexpression in the SN on FR5 cocaine self-administration were seen $(N=$ 4/group). c, No effects of GluR1 ${ }^{\text {WT }}$ or GluR1 ${ }^{\text {S845A }}$ overexpression in the VTA on the highest response/injection ratio completed (break point) on a progressive ratio schedule of sucrose pellet reinforcement were seen ( $N=6 /$ group). $\boldsymbol{d}$, No effects of GluR1 ${ }^{\mathrm{WT}}$ or GluR1 ${ }^{\mathrm{S} 44 \mathrm{~A}}$ overexpression in the $\mathrm{SN}$ on the highest response/injection ratio completed (break point) on a progressive ratio schedule of cocaine $(1 \mathrm{mg} / \mathrm{kg}$ per injection) reinforcement were seen $(N=$ 4/group). $\boldsymbol{e}, \boldsymbol{f}$, Histological localization of HSV-GluR1 infusion sites in the VTA (e) and SN (f). Data are expressed as mean \pm SEM.

intra-VTA infusions (Fig. $5 c, f$ ), consistent with the transient overexpression profile of these HSV vectors described previously (Carlezon et al., 1997; Sutton et al., 2003; Bachtell et al., 2008). There was no effect of the PKC/CaMKII-resistant GluR1 ${ }^{\text {S831A }}$ mutant in either fixed or progressive ratio self-administration testing.

To determine whether the effects of overexpressed GluR 1 WT and GluR $1^{\text {S845A }}$ in VTA neurons produced generalized effects on reinforcement mechanisms or response capacity, the HSVGluR $1^{\text {WT }}$ and HSV-GluR $1^{\text {S845A }}$ vectors were infused into the VTA of rats trained to self-administer sucrose pellets on similar fixed and progressive ratio reinforcement schedules. Neither GluR1 ${ }^{\text {WT }}$ nor GluR1 ${ }^{\text {S845A }}$ overexpression in VTA neurons altered the rate of sucrose pellet self-administration on the fixed ratio schedule, or the level of effort exerted for sucrose pellets on the progressive ratio reinforcement schedule (Fig. $6 a, c$ ), indicating specific alterations in cocaine reinforcement. In addition, when HSV-GluR1 ${ }^{\text {WT }}$ and HSV-GluR1 ${ }^{\text {S845A }}$ were infused into the adjacent $\mathrm{SN}$ region, there were no effects on fixed or progressive ratio cocaine self-administration (Fig. $6 b, d$ ), indicating that cocaine reinforcement is altered by GluR $1^{\text {WT }}$ and GluR $1^{\text {S845A }}$ overexpression specifically in the mesolimbic dopamine pathway.
Figure $6, e$ and $f$, shows the anatomical location of HSV infusion sites in the VTA and the SN, respectively, based on histological confirmation for all animals included in this study.

\section{Discussion}

\section{Dynamic regulation of GluR1 and GluR2 during daily} cocaine self-administration

We found that chronic daily cocaine self-administration produces reinforcement-related upregulation in AMPA, but NMDA, glutamate receptor subunits in the VTA. This upregulation consists of increases in GluR1 and GluR2 AMPA receptor subunits after $1 \mathrm{~d}$ withdrawal from cocaine self-administration and a corresponding increase in PKA-mediated GluR1 ${ }^{\mathrm{S} 845}$ phosphorylation, without increasing PKC/CaMKII-mediated GluR1 ${ }^{\text {S831 }}$ phosphorylation. GluR $1^{\mathrm{S} 845}$ phosphorylation facilitates both dendritic and extrasynaptic membrane trafficking of GluR1-containing AMPA receptors, whereas GluR $1^{\text {S831 }}$ phosphorylation facilitates translocation to synaptic membranes in hippocampal neurons (Song and Huganir, 2002; Esteban et al., 2003; Derkach et al., 2007; Kessels et al., 2009). Thus, an abundance of phosphorylated GluR $1^{\mathrm{S} 845}$-containing AMPA receptors could promote extrasynaptic membrane incorporation of AMPA receptors that are primed for synaptic translocation with subsequent activitydependent GluR1 ${ }^{\text {S831 }}$ phosphorylation in VTA neurons, granted that similar trafficking mechanisms exist in both hippocampal and VTA neurons. In this regard, our results parallel the development of LTP in excitatory synapses on VTA dopamine neurons that occurs specifically in animals that self-administer cocaine, and not in animals receiving cocaine by passive yoked injection (Chen et al., 2008). However, in contrast to the prolonged (up to 3 months withdrawal) enhancement of excitatory responses in VTA dopamine neurons reported by Chen et al. (2008), we found that upregulation of GluR1 and GluR2 is no longer detected after 3 week withdrawal from cocaine self-administration. Thus, although reinforcement-related upregulation in GluR1 and GluR2 could contribute to the initial development of LTP in selfadministering animals, other enduring mechanisms may underlie its persistence.

Increases in GluR1 protein are likely mediated by increased gene expression since cocaine self-administration also increased GluR1 mRNA. One potential mechanism could involve an increase in extracellular glutamate levels in the VTA that occur only in cocaine self-administering animals and not in their yoked partners (You et al., 2007). Thus, a glutamate-NMDA receptor-Ca ${ }^{++}$ signaling cascade culminating in a reinforcement-specific increase in GluR1 expression could account for these findings. Another possibility is that BDNF-TrkB receptor signaling could contribute to GluR1 upregulation, since BDNF increases GluR1 expression in cultured hippocampal neurons (Caldeira et al., 2007), and LTP in VTA dopamine neurons is facilitated by BDNF during withdrawal from cocaine administration (Pu et al., 2006). Whether the latter response would be specific to self-administration behavior is unknown. In contrast to GluR1, increases in GluR2 protein were accompanied by decreases in GluR2 mRNA. GluR2 subunits are recycled constitutively and inserted into synaptic membranes independent of activity/phosphorylation changes (Passafaro et al., 2001; Shi et al., 2001). However, since GluR1 ${ }^{\text {S845 }}$ phosphorylation promotes membrane stabilization and protection from lysosomal degradation (He et al., 2009), it is possible that an upregulation in phosphorylated GluR1 ultimately would form protective heteromers with GluR2 and account for increases in GluR2 after $1 \mathrm{~d}$ withdrawal from cocaine self-administration. 
Our results suggest that transient increases in GluR1 and GluR2, along with decreases in GluR2 mRNA, are dynamically modulated by daily cocaine use patterns, as these changes were obliterated after engaging in subsequent cocaine self-administration. Normalization of GluR1 during cocaine self-administration could involve NMDAmediated dephosphorylation of GluR $1{ }^{\mathrm{S} 845}$ leading to internalization and degradation (He et al., 2009). In any event, such dynamic increases in VTA AMPA receptors could contribute to daily cocaine use by facilitating the excitability of VTA dopamine neurons in response to environmental cues or stress that activate these neurons (see Introduction) and trigger craving responses in human cocaine addicts (Robbins et al., 1997; Sinha et al., 1999). We also found that the ability of cocaine to directly increase PKAmediated GluR $1^{\mathrm{S} 845}$ phosphorylation in the VTA is reduced after chronic administration, similar to our previous findings in striatal and amygdalar subregions, but not in cortical or hippocampal subregions (Edwards et al., 2007). These results suggest that a generalized tolerance develops to cocaine-induced GluR $1^{\mathrm{S} 845}$ phosphorylation throughout the mesolimbic dopamine system with chronic cocaine exposure.

Several studies have reported increases in AMPA or NMDA receptor subunits in the VTA after repeated passive cocaine administration via intraperitoneal injections (Fitzgerald et al., 1996; Churchill et al., 1999), whereas others have not (Lu et al., 2001). These changes have been related to short-term increases in the excitability of VTA dopamine neurons (White et al., 1995; Zhang et al., 1997; Saal et al., 2003). Given these previous findings, the lack of GluR1 or GluR2 upregulation with repeated passive administration by yoked cocaine injections is unclear, but could relate to the intravenous route of administration or the higher cocaine dose received with $4 \mathrm{~h}$ of administration. For example, a single intraperitoneal cocaine injection can induce LTP in VTA dopamine neurons (Ungless et al., 2001), whereas yoked intravenous injections fail to induce these changes (Chen et al., 2008). In regard to cocaine self-administration, one study found reductions in the GluR5 and NR1 glutamate receptor subunits in the VTA of rats $15-16 \mathrm{~h}$ after prolonged daily access $(8 \mathrm{~h})$ in rats, but no change in GluR1 and GluR2 protein (Hemby et al., 2005). Another study found that GluR2 levels were upregulated in the VTA of human cocaine overdose victims (Tang et al., 2003). Yet another study found that NR2A and NR2B protein levels are not altered in the VTA after brief or extended access to cocaine selfadministration (Ben-Shahar et al., 2009), in agreement with a lack of NMDA receptor subunit regulation in the present study. Our results demonstrate that GluR1 and GluR2 regulation is highly dynamic during daily cocaine use, oscillating from increases after $1 \mathrm{~d}$ withdrawal to normalization immediately after self-administration, which could account for much of this discrepancy.

\section{Functional role of GluR1 upregulation in cocaine self-administration}

We used HSV viral vectors to study the role of reinforcementrelated GluR1 upregulation in the VTA on cocaine selfadministration behavior. Although dopamine neurons were not targeted genetically, the vectors were infused in a VTA region rich in dopamine neurons, resulting in a three-to-one ratio of dopamine to nondopamine neuronal infection. Electrophysiological recordings from putative VTA dopamine neurons indicate that HSV-mediated GluR1 overexpression increased membrane rectification but not peak currents with AMPA receptor stimulation, consistent with membrane insertion of newly synthesized GluR2lacking AMPA receptors that replace existing AMPA receptors, and similar to the LTP induced by a single cocaine injection (Bellone and Luscher, 2006). The enhancement of AMPA-mediated (but not NMDA-mediated) locomotion confirmed the functional activity of GluR1 overexpression in vivo.

Transient overexpression of GluR1 in VTA neurons also markedly enhanced cocaine reinforcement by almost tripling the degree of lever-press behavior rats would engage to maintain cocaine intake at a high injection dose. These changes occurred in the absence of overt alterations in responses for a natural reward (sucrose) or in the stable regulation of cocaine intake under less demanding self-administration schedules. In addition, the effect was related specifically to GluR1 overexpression in the mesolimbic dopamine cell body region. These results suggest that dynamic upregulation of GluR1 in the VTA produced specifically by the reinforcing context of cocaine self-administration would act reciprocally to strengthen the reinforcing efficacy of cocaine on subsequent self-administration occasions. The reinforcing efficacy of cocaine returned to control levels after dissipation of GluR1 overexpression, indicating a direct effect of GluR1 in the VTA on cocaine reinforcement. Given that endogenous GluR1 upregulation also normalized after longer cocaine withdrawal, such transient increase in GluR1 could facilitate cocaine addiction by prolonging daily self-administration binges.

Although the PKC/CaMKII-resistant GluR $1^{\text {S831A }}$ did not alter cocaine reinforcement, it is surprising that the PKA-resistant mutant GluR $1^{\text {S845A }}$ attenuated low-dose cocaine reinforcement when overexpressed in the VTA. Overexpressed GluR $1^{\text {S845A }}$ failed to reach dendritic processes in VTA neurons, suggesting a necessary role for GluR $1^{\mathrm{S} 845}$ phosphorylation in dendritic trafficking and complementing recent findings that enhanced GluR ${ }^{\mathrm{S} 845}$ phosphorylation increases dendritic trafficking (Kessels et al., 2009). The lack of dendritic trafficking with the GluR $1{ }^{\text {S845A }}$ mutant could promote a dominant-negative effect by interacting with endogenous GluR1 and GluR2 subunits and impeding their trafficking through dendritic processes. Although similar dominant-negative interactions are prevalent in the literature, further work is needed to elucidate the mechanism for the attenuation of reinforcement by GluR $1^{\mathrm{S} 845 \mathrm{~A}}$ at lower cocaine injection doses. Nevertheless, our results indicate that PKAmediated GluR $1^{\mathrm{S} 845}$ phosphorylation is necessary for GluR1 ${ }^{\mathrm{WT}}$ enhancement of cocaine reinforcement.

Vulnerability to cocaine self-administration is associated with enhanced excitability of VTA dopamine neurons in rats (Marinelli and White, 2000), and blockade of ionotropic glutamate receptors in the VTA attenuates relapse to cocaine-seeking behavior (Vorel et al., 2001; Sun et al., 2005). Furthermore, neuroadaptations leading to LTP in VTA dopamine neurons are necessary to induce subsequent neuroplasticity in target regions such as the nucleus accumbens (Mameli et al., 2009), although other behavioral responses to cocaine such as conditioned place preference and locomotor sensitization are unaltered by selective loss of GluR1 in midbrain dopamine neurons (Engblom et al., 2008). Given that repeated electrical stimulation of the lateral hypothalamus reduces both GluR1 levels in the VTA and cocaine-seeking (but not sucrose-seeking) behavior in rats (Levy et al., 2007), the amelioration of reinforcement-related GluR1 upregulation reported here may have therapeutic efficacy. Treatments that preclude such dynamic regulation of AMPA glutamate receptors during ongoing cocaine use could also prevent the vicious cycle of cocaine-seeking and cocaine-taking behavior that leads to cocaine addiction in humans. 


\section{References}

Bachtell RK, Choi KH, Simmons DL, Falcon E, Monteggia LM, Neve RL, Self DW (2008) Role of GluR1 expression in nucleus accumbens neurons in cocaine sensitization and cocaine-seeking behavior. Eur J Neurosci 27: $2229-2240$

Bellone C, Luscher C (2006) Cocaine triggered AMPA receptor redistribution is reversed in vivo by mGluR-dependent long-term depression. Nat Neurosci 9:636-641.

Ben-Shahar O, Obara I, Ary AW, Ma N, Mangiardi MA, Medina RL, Szumlinski KK (2009) Extended daily access to cocaine results in distinct alterations in Homer $1 \mathrm{~b} / \mathrm{c}$ and NMDA receptor subunit expression within the medial prefrontal cortex. Synapse 63:598-609.

Berridge KC, Robinson TE (1998) What is the role of dopamine in reward: hedonic impact, reward learning, or incentive salience? Brain Res Rev 28:309-369.

Borgland SL, Malenka RC, Bonci A (2004) Acute and chronic cocaineinduced potentiation of synaptic strength in the ventral tegmental area: electrophysiological and behavioral correlates in individual rats. J Neurosci 24:7482-7490.

Caldeira MV, Melo CV, Pereira DB, Carvalho R, Correia SS, Backos DS, Carvalho AL, Esteban JA, Duarte CB (2007) Brain-derived neurotrophic factor regulates the expression and synaptic delivery of alpha-amino-3-hydroxy-5methyl-4-isoxazole propionic acid receptor subunits in hippocampal neurons. J Biol Chem 282:12619-12628.

Cao JL, Covington HE III, Friedman AK, Wilkinson MB, Walsh JJ, Cooper DC, Nestler EJ, Han MH (2010a) Mesolimbic dopamine neurons in the brain reward circuit mediate susceptibility to social defeat and antidepressant action. J Neurosci 30:16453-16458.

Cao JL, Vialou VF, Lobo MK, Robison AJ, Neve RL, Cooper DC, Nestler EJ, Han MH (2010b) Essential role of the cAMP-cAMP response-element binding protein pathway in opiate-induced homeostatic adaptations of locus coeruleus neurons. Proc Natl Acad Sci U S A 107:17011-17016.

Carlezon WAJ, Boundy VA, Haile CN, Kalb RG, Neve RL, Nestler EJ (1997) Sensitization to morphine induced by viral-mediated gene transfer. Science 277:812-814.

Chen BT, Bowers MS, Martin M, Hopf FW, Guillory AM, Carelli RM, Chou JK, Bonci A (2008) Cocaine but not natural reward self-administration nor passive cocaine infusion produces persistent LTP in the VTA. Neuron 59:288-297.

Choi KH, Rahman Z, Edwards S, Hall S, Neve RL, Self DW (2003) Opposite effects of GluR1 and PKA-resistant GluR1 overexpression in the ventral tegmental area on cocaine reinforcement. Ann NY Acad Sci 1003:372374.

Churchill L, Swanson CJ, Urbina M, Kalivas PW (1999) Repeated cocaine alters glutamate receptor subunit levels in the nucleus accumbens and ventral tegmental area of rats that develop behavioral sensitization. J Neurochem 72:2397-2403.

Derkach VA, Oh MC, Guire ES, Soderling TR (2007) Regulatory mechanisms of AMPA receptors in synaptic plasticity. Nat Rev Neurosci 8:101-113.

Donovan MH, Yamaguchi M, Eisch AJ (2008) Dynamic expression of TrkB receptor protein on proliferating and maturing cells in the adult mouse dentate gyrus. Hippocampus 18:435-439.

Dworkin SI, Co C, Smith JE (1995) Rat brain neurotransmitter turnover rates altered during withdrawal from chronic cocaine administration. Brain Res 682:116-126.

Edwards S, Graham DL, Bachtell RK, Self DW (2007) Region-specific tolerance to cocaine-regulated cAMP-dependent protein phosphorylation following chronic self-administration. Eur J Neurosci 25:2201-2213.

Engblom D, Bilbao A, Sanchis-Segura C, Dahan L, Perreau-Lenz S, Balland B, Parkitna JR, Lujan R, Halbout B, Mameli M, Parlato R, Sprengel R, Luscher C, Schutz G, Spanagel R (2008) Glutamate receptors on dopamine neurons control the persistence of cocaine seeking. Neuron 59:497-508.

Esteban JA, Shi SH, Wilson C, Nuriya M, Huganir RL, Malinow R (2003) PKA phosphorylation of AMPA receptor subunits controls synaptic trafficking underlying plasticity. Nat Neurosci 6:136-143.

Fitzgerald LW, Ortiz J, Hamedani AG, Nestler EJ (1996) Drugs of abuse and stress increase the expression of GluR1 and NMDAR1 glutamate receptor subunits in the rat ventral tegmental area: common adaptations among cross-sensitizing agents. J Neurosci 16:274-282.

Freeman WM, Brebner K, Patel KM, Lynch WJ, Roberts DC, Vrana KE
(2002) Repeated cocaine self-administration causes multiple changes in rat frontal cortex gene expression. Neurochem Res 27:1181-1192.

Han MH, Bolanos CA, Green TA, Olson VG, Neve RL, Liu RJ, Aghajanian GK, Nestler EJ (2006) Role of cAMP response element-binding protein in the rat locus ceruleus: regulation of neuronal activity and opiate withdrawal behaviors. J Neurosci 26:4624-4629.

He K, Song L, Cummings LW, Goldman J, Huganir RL, Lee HK (2009) Stabilization of Ca2 +-permeable AMPA receptors at perisynaptic sites by GluR1S845 phosphorylation. Proc Natl Acad Sci U S A 106:20033-20038.

Hemby SE, Co C, Koves TR, Smith JE, Dworkin SI (1997) Differences in extracellular dopamine concentrations in the nucleus accumbens during response-dependent and response-independent cocaine administration in the rat. Psychopharmacology 133:7-16.

Hemby SE, Horman B, Tang W (2005) Differential regulation of ionotropic glutamate receptor subunits following cocaine self-administration. Brain Res 1064:75-82.

Jacobs EH, Spijker S, Verhoog CW, Kamprath K, de Vries TJ, Smit AB, Schoffelmeer AN (2002) Active heroin administration induces specific genomic responses in the nucleus accumbens shell. FASEB J 16:1961-1963.

Kessels HW, Kopec CD, Klein ME, Malinow R (2009) Roles of stargazin and phosphorylation in the control of AMPA receptor subcellular distribution. Nat Neurosci 12:888-896.

Krishnan V, Han MH, Graham DL, Berton O, Renthal W, Russo SJ, Laplant Q, Graham A, Lutter M, Lagace DC, Ghose S, Reister R, Tannous P, Green TA, Neve RL, Chakravarty S, Kumar A, Eisch AJ, Self DW, Lee FS, et al. (2007) Molecular adaptations underlying susceptibility and resistance to social defeat in brain reward regions. Cell 131:391-404.

Kumar A, Choi KH, Renthal W, Tsankova NM, Theobald DE, Truong HT, Russo SJ, Laplant Q, Sasaki TS, Whistler KN, Neve RL, Self DW, Nestler EJ (2005) Chromatin remodeling is a key mechanism underlying cocaineinduced plasticity in striatum. Neuron 48:303-314.

Levy D, Shabat-Simon M, Shalev U, Barnea-Ygael N, Cooper A, Zangen A (2007) Repeated electrical stimulation of reward-related brain regions affects cocaine but not "natural" reinforcement. J Neurosci 27:14179-14189.

Liu QS, Pu L, Poo MM (2005) Repeated cocaine exposure in vivo facilitates LTP induction in midbrain dopamine neurons. Nature 437:1027-1031.

Lu W, Monteggia LM, Wolf ME (2001) Repeated administration of amphetamine and cocaine does not alter AMPA receptor subunit expression in the rat midbrain. Neuropsychopharmacology 26:1-13.

Malinow R, Malenka RC (2002) AMPA receptor trafficking and synaptic plasticity. Annu Rev Neurosci 25:103-126.

Mameli M, Halbout B, Creton C, Engblom D, Parkitna JR, Spanagel R, Luscher C (2009) Cocaine-evoked synaptic plasticity: persistence in the VTA triggers adaptations in the NAc. Nat Neurosci 12:1036-1041.

Marinelli M, White FJ (2000) Enhanced vulnerability to cocaine selfadministration is associated with elevated impulse activity of midbrain dopamine neurons. J Neurosci 20:8876-8885.

Mark GP, Hajnal A, Kinney AE, Keys AS (1999) Self-administration of cocaine increases the release of acetylcholine to a greater extent than response-independent cocaine in the nucleus accumbens of rats. Psychopharmacology 143:47-53.

Miguens M, Crespo JA, Del Olmo N, Higuera-Matas A, Montoya GL, GarciaLecumberri C, Ambrosio E (2008) Differential cocaine-induced modulation of glutamate and dopamine transporters after contingent and noncontingent administration. Neuropharmacology 55:771-779.

Passafaro M, Piech V, Sheng M (2001) Subunit-specific temporal and spatial patterns of AMPA receptor exocytosis in hippocampal neurons. Nat Neurosci 4:917-926.

Paxinos G, Watson GC (1998) The rat brain in stereotaxic coordinates, Ed 4. New York: Academic.

Phillips PE, Stuber GD, Heien ML, Wightman RM, Carelli RM (2003) Subsecond dopamine release promotes cocaine seeking. Nature 422:614-618.

$\mathrm{Pu}$ L, Liu QS, Poo MM (2006) BDNF-dependent synaptic sensitization in midbrain dopamine neurons after cocaine withdrawal. Nat Neurosci 9:605-607.

Robbins SJ, Ehrman RN, Childress AR, O’Brien CP (1997) Relationships among physiological and self-report responses produced by cocainerelated cues. Addict Behav 22:157-167.

Saal D, Dong Y, Bonci A, Malenka RC (2003) Drugs of abuse and stress trigger a common synaptic adaptation in dopamine neurons. Neuron $37: 577-582$ 
Schmidt EF, Sutton MA, Schad CA, Karanian DA, Brodkin ES, Self DW (2001) Extinction training regulates tyrosine hydroxylase during withdrawal from cocaine self-administration. J Neurosci 21:RC137.

Self DW, Choi KH (2004) Extinction-induced neuroplasticity attenuates stress-induced cocaine seeking: a state-dependent learning hypothesis. Stress 7:145-155.

Self DW, Nestler EJ (1998) Relapse to drug seeking: neural and molecular mechanisms. Drug Alcohol Depend 51:49-60.

Shalev U, Grimm JW, Shaham Y (2002) Neurobiology of relapse to heroin and cocaine seeking: a review. Pharmacol Rev 54:1-42.

Shi S-H, Hayashi Y, Esteban JA, Malinow R (2001) Subunit-specific rules governing AMPA receptor trafficking to synapses in hippocampal pyramidal neurons. Cell 105:331-343.

Sinha R, Catapano D, O’Malley S (1999) Stress induced craving and stress response in cocaine dependent individuals. Psychopharmacology 142:343-351.

Song I, Huganir RL (2002) Regulation of AMPA receptors during synaptic plasticity. Trends Neurosci 25:578-588.

Stefanski R, Ziolkowska B, Kusmider M, Mierzejewski P, Wyszogrodzka E, Kolomanska P, Dziedzicka-Wasylewska M, Przewlocki R, Kostowski W (2007) Active versus passive cocaine administration: differences in the neuroadaptive changes in the brain dopaminergic system. Brain Res 1157:1-10.

Stewart J (1983) Conditioned and unconditioned drug effects in relapse to opiate and stimulant drug self-adminstration. Prog Neuropsychopharmacol Biol Psychiat 7:591-597.

Stewart J (2000) Pathways to relapse: the neurobiology of drug- and stressinduced relapse to drug-taking. J Psychiat Neurosci 25:125-136.

Sun W, Akins CK, Mattingly AE, Rebec GV (2005) Ionotropic glutamate receptors in the ventral tegmental area regulate cocaine-seeking behavior in rats. Neuropsychopharmacology 30:2073-2081.

Sutton MA, Schmidt EF, Choi K-H, Schad CA, Whisler K, Simmons D, Karanian DA, Monteggia LM, Neve RL, Self DW (2003) Extinction- induced up-regulation in AMPA receptors reduces cocaine-seeking behaviour. Nature 421:70-75.

Tang WX, Fasulo WH, Mash DC, Hemby SE (2003) Molecular profiling of midbrain dopamine regions in cocaine overdose victims. J Neurochem 85:911-924.

Thomas KL, Arroyo M, Everitt BJ (2003) Induction of the learning and plasticity-associated gene Zif268 following exposure to a discrete cocaineassociated stimulus. Eur J Neurosci 17:1964-1972.

Ungless MA, Whistler JL, Malenka RC, Bonci A (2001) Single cocaine exposure in vivo induces long-term potentiation in dopamine neurons. Nature 411:583-587.

Ungless MA, Singh V, Crowder TL, Yaka R, Ron D, Bonci A (2003) Corticotropin-releasing factor requires CRF binding protein to potentiate NMDA receptors via CRF receptor 2 in dopamine neurons. Neuron 39:401-407.

Vorel SR, Liu X, Hayes RJ, Spector JA, Gardner EL (2001) Relapse to cocaine-seeking after hippocampal theta burst stimulation. Science 292:1175-1178

White FJ, Hu XT, Zhang XF, Wolf ME (1995) Repeated administration of cocaine or amphetamine alters neuronal responses to glutamate in the mesoaccumbens dopamine system. J Pharmacol Exp Ther 273:445-454.

Wilson JM, Nobrega JN, Corrigall WA, Coen KM, Shannak K, Kish SJ (1994) Amygdala dopamine levels are markedly elevated after self- but not passive-administration of cocaine. Brain Res 668:39-45.

You ZB, Wang B, Zitzman D, Azari S, Wise RA (2007) A role for conditioned ventral tegmental glutamate release in cocaine seeking. J Neurosci 27:10546-10555.

Zhang H, Kiyatkin EA, Stein EA (1994) Behavioral and pharmacological modulation of ventral tegmental dendritic dopamine release. Brain Res 656:59-70

Zhang XF, Hu XT, White FJ, Wolf ME (1997) Increased responsiveness of ventral tegmental area dopamine neurons to glutamate after repeated administration of cocaine or amphetamine is transient and selectively involves AMPA receptors. J Pharmacol Exp Ther 281:699-706. 